\title{
Improving students' critical thinking skills using time bar media in mathemathics learning in the third-grade primary school
}

\author{
Wahyu Purwaningsih *, Muhammad Nur Wangid \\ Universitas Negeri Yogyakarta. J1. Colombo No. 1, Karangmalang, Yogyakarta 55281, Indonesia \\ * Corresponding Author. E-mail: wahyupurwaningsih.2019@student.uny.ac.id
}

Received: 15 March 2021; Revised: 6 April 2021; Accepted: 10 May 2021

\begin{abstract}
This study aims to improve the students' critical thinking skills using time bar media in mathematics learning for in grade IIIA of State Primary School Kotagede I. It used classroom action research as design by Kemmis and McTaggart. The subjects of this research were grade 3th State Primary School Kotagede I with a total of 30 students. The data were collected through observation, written tests, and interviews. The research instrument used was the teacher's activity observation sheet in mathematics learning, written test questions, and interview guides for teachers and students. The instrument of the test each test question there are 6 items in the description. The obtained data were analyzed using descriptive quantitative and qualitative techniques. The results showed that the use of time bar media in mathematics learning could improve students' critical thinking skills. The critical thinking skills covered: providing simple explanations, building basic skills, concluding, providing further explanations, and arranging strategies and tactics. The increase in students' critical thinking skills was seen based on the test results in the pre-action (43\%) which increased to $80 \%$ in the first cycle and increased to $90 \%$ in the second cycle.
\end{abstract}

Keywords: students', critical thinking skills, time bar media

How to Cite: Purwaningsih, W., \& Wangid, M. (2021). Improving students' critical thinking skills using time bar media in mathemathics learning in the third-grade primary school. Jurnal Prima Edukasia, 9(2), 248-260. doi:https://doi.org/10.21831/jpe.v9i2.39429

\section{Introduction}

Thinking skills are important and highly required in the 21 st century and it is in line with (Ahonen \& Kinnunen, 2015; Dixon, 2017) argue that critical thinking skills are highly valued in this era in which educational practices emphasize basic skills including reading, writing, and arithmetic with less consideration to equip students with skills to face the current challenges. The 2013 Curriculum needs students to be able to master technological development, critical thinking and broad insights and to emphasize the importance of skills og the 21 st century. Critical thingking skills are among the most important life skills for students of the 21 st century. This skills is considered a key to achieving a goal for ner knowledge-based education and economy (Changwong et al., 2018; Jones \& Pimdee, 2017). Criticak thinking skills not only illustrate the ability to think according to the rules of logic and probability, but also the ability to make decisions or solve problems in real life and socciety (Karakoc, 2016; Murawski, 2012; Zulmaulida et al., 2018). Students' critical thinking skills are needed to deal with various kinds of problems in the globalization era. Critical thinking is crucial so that it becomes one of the main goals in education (Johnson, 2011; Sari \& Suyanta, 2021).

Based on the results of interviews with teachers and students and observations of the learning process in grade III of State Primary School Kotagede 1, the researcher found several problems in mathematics learning. They covered unavailability of learning media which causing boring learning and low students' participation in learning, less varied learning process, monotonous and conventional learning methods, the dominant use of numerical symbols by the teacher, and low students' critical thinking skills in learning mathematics. Students' critical thinking skills in mathematics learning are low based on the following evidence. First, no student takes the initiative to answer the teacher's questions and they sometimes only responded to the teacher's questions based on memory while the students' understanding of the concept is limited. Critical thinking is not only limited to cognitive thinking ability but critical thinking also involves activation of students in the learning classroom. As told by Welch et al. (2015) critical thinking also involves students' active skills in administering both affective and psychological 
Jurnal Prima Edukasia, 9 (2), 2021 - 249

Wahyu Purwaningsih, Muhammad Nur Wangid

to involved self-ability in identifying and information source analysis for credibility, showing previous knowledge and making connections, and drawing conclusions.

Students could not analyze and solve problems in mathematics. It resulted in low critical thinking skills with lower average scores (56) in mathematics learning outcomes compared to other subjects. Changwong et al. (2018) stated the scores was derived from the results of students' learning at a formative assessment. Student who master the ability to think critically will perform better academically and will also be better prepared to received higher learning.

Second, teacher tends to communicate in one way and use monotonous methods dominated by lectures and assignments. Thus, it caused students' lower understanding of learning mathematics. Learning that does not facilitate students to connect and see their relevance to their daily environment tends to result in a lack of participation and difficulty achieving or maintaining information that is presented (Hootstein, 1994; Wallace, 2015). This is certainly a gap in the expected situation, because basically, teacher performance greatly affects the quality of learning (Tjabolo \& Herwin, 2020).

Students only listened to and recorded what the teacher says. Third, only a few students dared to propose questions to the teacher. Fourth, students still waited to be appointed by the teacher to answer questions or express their opinions. Indeed, some students responded to the teacher's questions with incorrect answers. The students' answers were limited to memorization because the concept of learning mathematics was only obtained from the teacher's lectures and thematic books. When students were asked to do the assignment in front of the class, most of them could not do it well. Fifth, there was no question and answer section among students. Sixth, the teacher had not provided evaluation questions to stimulate the students' critical thinking skills. Further, students could not construct their knowledge because they only received materials from lecturing and thematic books. They were not motivated to actively learn due to the application of one-way learning or lecturing method.

Besides, the insufficient availability of media also hinders the effectiveness of learning, especially for low-grade students who need to feel what they see in learning. Media can make the abstract concept more concrete enabling students to learn according to their learning development stages. (Brookhart \& Nitko, 2019) stated that indicators of critical thinking are easier to make and apply to mathematics learning in primary schools by using learning media. (Chusni et al., 2020; Davidson \& Dunham, 1997) dividing the components of critical thinking ability there are five indicators that make up critical thinking ability. The five aspects can describe as follows: (1) providing simple explanations; (2) building basic skills; (3) drawing conclusions, (4) providing further explanations; (5) arranging strategies and tactics.

Scott (2008) stated that critical thinking skills should be integrated into other competencies such as the media of learning and mathematical learning. So it can be improved students' critical thinking skills. It is based on the consideration that cognitively, grade III of primary school students are at the concrete operational thinking stage in which critical thinking skills have just developed.

Critical thinking skills are important for students. They become an important educational goal to prepare students to be able to identify and analyze the credibility of sources of information, demonstrate prior knowledge, make a connection, and draw conclusions (Duron et al., 2006; Welch et al., 2015). Critical thinking skill is one that focused on an event or a problem. The events or problem is then analyzed the underlying factors and how the problem can occur, that the critical thinking skills cause students to become more active in searching for information that supports righteousness (Farindhani \& Wangid, 2019; Rasiman, 2012). Critical thinking with precise, logical, and fast problem solving is required to prepare students to face personal challenges and future careers (Robbins \& Judge, 2017). Critical thinking is the application of careful reasoning in determining whether a statement is true (B. N. Moore \& Parker, 2014). The development of critical thinking skills can be done by utilizing learning media. Learning media can increase active participation and develop students' critical thinking skills (Buckingham, 2008). The use of learning media can direct the students' attention, increase motivation, improve learning achievement, and improve critical thinking skills because the present materials clearer and easier to understand (Courville, 2011; Heo, 2012). Learning media are beneficial to provide more understanding to improve students' critical thinking skills and learning motivation. Association for Educational Communications and Technology (AECT, 2021) stated that media are all tools, forms, and channels to convey information.

This study used time bar media. Bars or rulers or are visual-based media are considered as nonprojection types of visual media, namely models, print, and graphic media (Smaldino et al., 2010). The time bar media is a substitute for a ruler. In this case, the size of the time frame is enlarged than the 
Jurnal Prima Edukasia, 9 (2), 2021 - 250

Wahyu Purwaningsih, Muhammad Nur Wangid

common ruler so that it is easily accessible by the students. Time bar media are also included in the type of graphic media as they were first designed using CorelDraw which covers the element of sketch, drawing, and line. Then after the design stage, the media were printed. The time bar media are included in the length measurement instrument. The instrument has the smallest scale of $1 \mathrm{~mm}$ or $0.1 \mathrm{~cm}$. The measurement accuracy is half of the smallest scale, namely $0.5 \mathrm{~mm}$. In performing the measurement, the sight must be perpendicular to the scale on the bar and the measured object. If not, it will result in errors with bigger or smaller sizes.

The time bar media functions to make it easier for students to understand the learning material conveyed by the teacher. This is reinforced by the fact that learning media are a tool to convey learning materials to facilitate the learning process based on the Regulation of the Ministry of Education and Culture Number 22/2016; (Adekola, 2010; Akay \& Gumusoglu, 2020; Menteri Pendidikan dan Kebudayaan Republik Indonesia, 2016). Educators have to be able to choose the appropriate learning media and method, active and create a conducive learning environment to achieve the learning objectives. One of the most important things to do is to encourage students in the process and model deep thought habits so that their critical thinking skills can be developed through the habit of critical questions provided by teachers and students' regular involvement the actively learning processes (Ingwarni, 2018).

The time bar media were taken from the word bar or ruler or ruler is a typical length measuring tool. In performing the measurements, the direction of sight must be perpendicular to the scale/number on the ruler and the measured object, otherwise, it will result in errors (Widodo, 2009). Meanwhile, time is a whole-time series of past, present, and future (Shihab, 2010). So the time bar media is a measuring functioned to measure the past, present, and future time to make it easier for students to understand the conveyed learning material. This time bar media is the media used in mathematics learning, particularly in time measurement material. This media is effective for increasing critical thinking skills (Putra \& Sudarti, 2015). Arke (2005) stated learning media can be a valuable tool in aiding the development of critical thinking skills. Providing media would help further the educational goals and objectives of many institutions to improve critical thinking as part overall curriculum.

The discussion in the article aims to: (1) answer the problem formulation and research questions; (2) shows how the findings were obtained; (3) interpret research findings; (4) linking research findings to established knowledge structures; and (5) bringing up new theories or modification of existing theories. This part of the discussion should contain the benefits of the research results, not the repetition results. The analysis must address the stated gap.

In answering the formulation of the problem and research questions, the results of the study must be concluded explicitly. Interpretation of findings is carried out using logic and existing theories. Findings in the form of reality in the field are integrated/linked with the results of previous studies or with existing theories. For this purpose, there must be a reference. In bringing up new theories, old theories can be confirmed or rejected, some may need to modify theories from old theories.

\section{Methods}

This Classroom Action Research (CAR) used a model developed by Kemmis and McTaggart which consists of four stages, namely: planning, action, observation, and reflection (Kemmis et al., 2014). This research was conducted at State Primary School Kotagede 1, Kotagede, Yogyakarta in the even semester of the 2018/2019 academic year from January-March 2019. The subjects in this study were 30 students in grade IIIA of State Primary School Kotagede 1. This research was conducted based on a cycle and each cycle consisted of four steps as suggested by Kemmis and McTaggart. The cycle would be stopped if it has reached the predetermined success criteria, otherwise, it would be continued. This classroom action research would be conducted using: (a) planning, (b) action, (c) observation, (d) reflection stages. Data were collected through observation and tests. The obtained data were analyzed using qualitative and quantitative data analysis techniques. The qualitative data were in the form of a description of the results of observations and evaluation of students' critical thinking skills in mathematics learning in each cycle. Meanwhile, the quantitative data were the result of the evaluation of students' critical thinking skills. The evaluation was carried out at the end of each cycle. The percentage of students' critical thinking skills was counted using the following formula. The interpretation of the percentage is categorized into the Table 1 (Arikunto, 2005). 
Jurnal Prima Edukasia, 9 (2), 2021 - 251

Wahyu Purwaningsih, Muhammad Nur Wangid

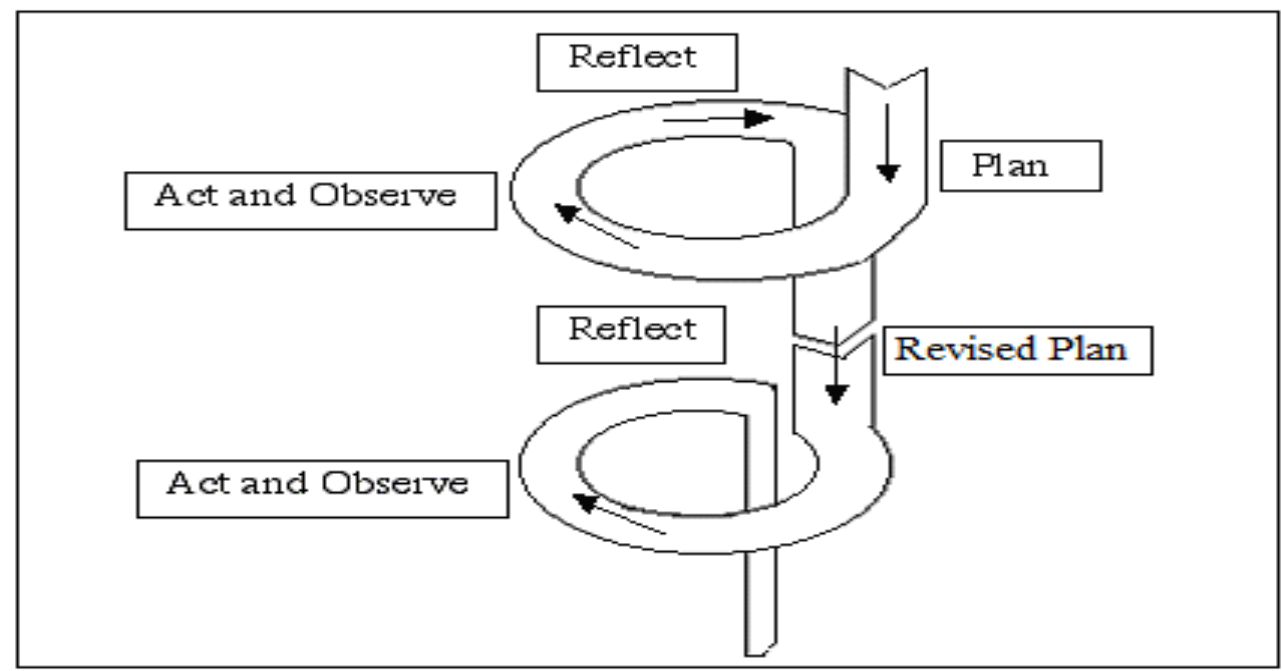

Figure 1. Kemmis and McTaggart's spiral model

Table 1. Categories of Critical Thinking Skills

\begin{tabular}{ccc}
\hline No. & Category & Achievement Score \\
\hline 1. & Very good & $80-100$ \\
2. & Good & $66-79$ \\
3. & Moderate & $56-65$ \\
4. & Low & $40-55$ \\
5. & Failed & $0-39$ \\
\hline
\end{tabular}

\section{Results and Discussions}

Planning

At this stage make the learning implement plan, then build the research instrument, which is an observation sheet and test matter, each test question there are 6 items in the description. An observation sheet is used to observe the wisdom of learning. The test issue used to measure the student's critical thinking ability is a six-issue description, preparing the necessary activity and learning media sheets and tools in the learning process. Each meeting, students are given an activity sheet that can support students' activities more specifically. As for the learning media in this study, it is the mainstream media. Preparing all forms of equipment that supported the course of research, such as a camera for documenting.

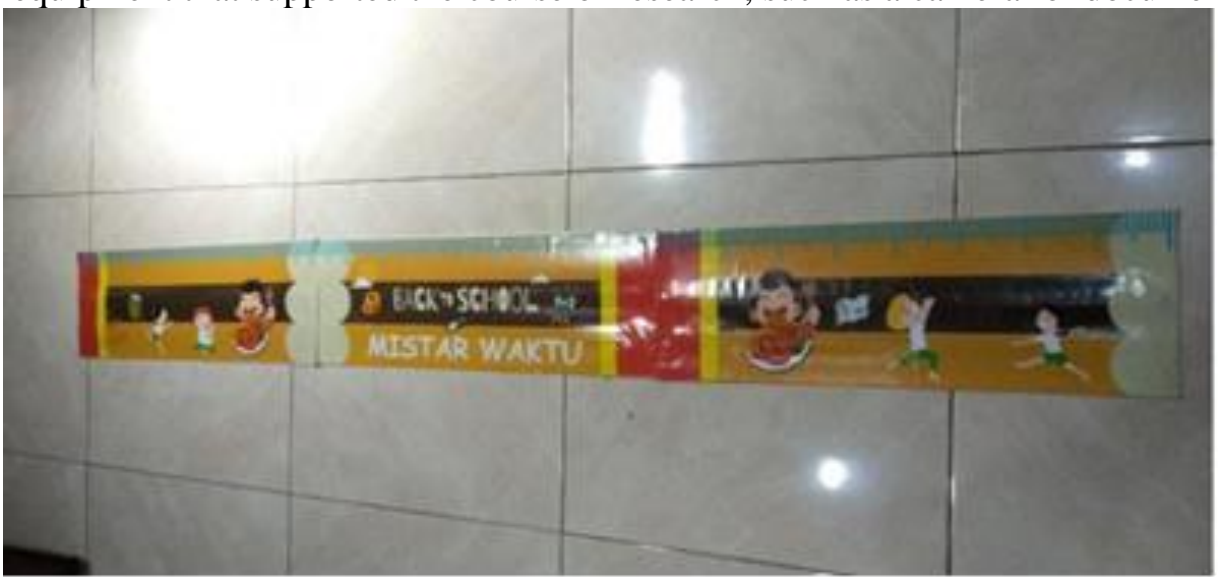

Figure 2. The Time Bar Media

Time-release media is used on the mathematical learning content of time measurement. The timetable media is also equipped with a number card that can be used to tell time and minutes. Tools used to create this time funnel were ruler, scissors, cutter, pencil, eraser, and paper plaster. The materials needed to make a time funnel were cardboard paper 2 sheets, HVS folio 10 sheets, A3 wrapping paper 4 sheets, magnet 300 grains. While the way of use of this time slide is to prepare the media of time and 
Jurnal Prima Edukasia, 9 (2), 2021 - 252

Wahyu Purwaningsih, Muhammad Nur Wangid

time CARDS (to show hours and minutes), the use of time-time media almost equal the use of a ruler, select a known number card, attach a number card to the time in the time bar, calculate each line in the time bar according to the question given by the teacher, attach a number card to the time dish according to the student's most correct answer, And students answer the problems given by the teacher on the paper provided by using the way.

Action

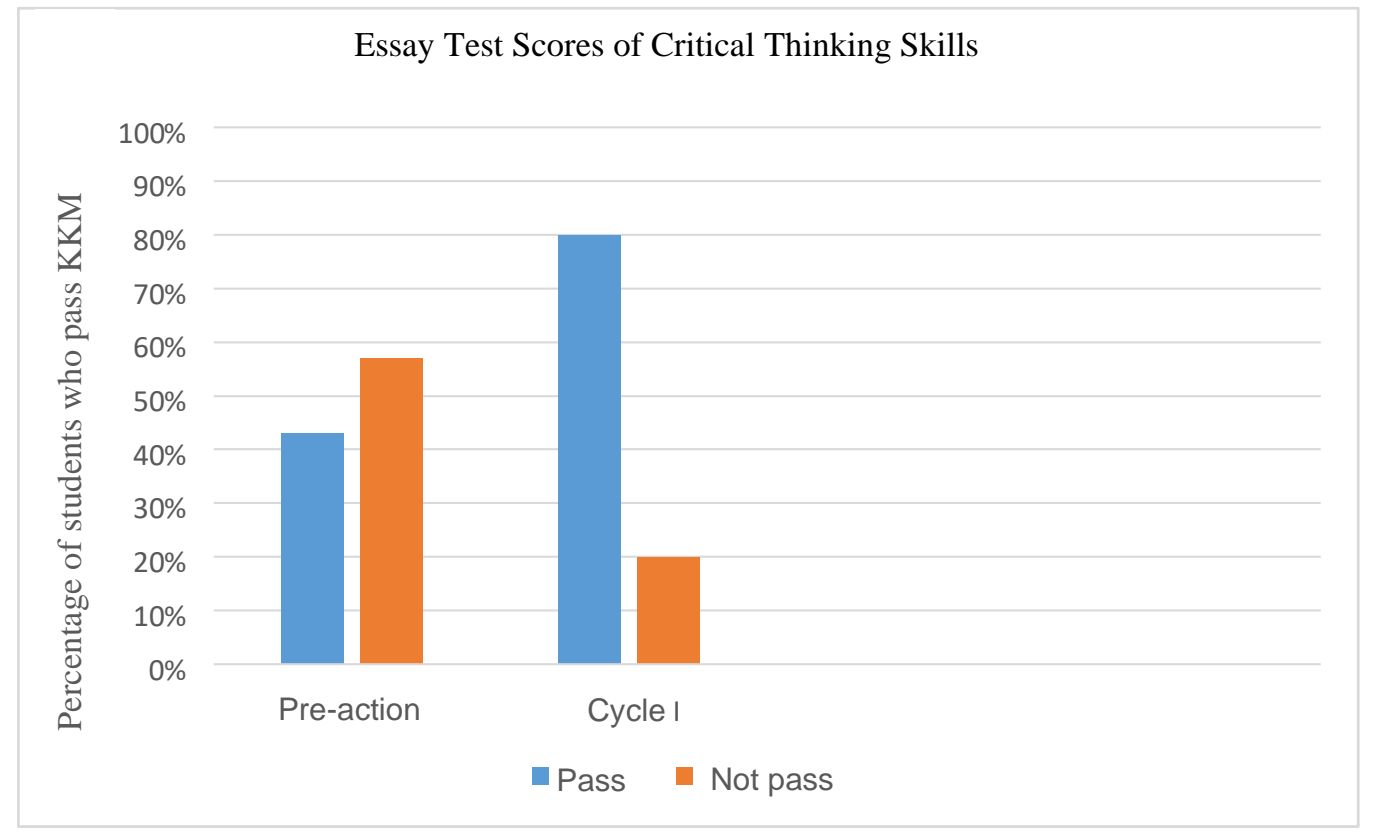

Figure 3. Diagram Comparison of Students' Critical Thinking Skill Test Results in Pre-action and Cycle I

Based on the Figure 3, the result of the test in cycle I showed a significant change in which in the pre-action action, the students worked on essay questions with $43 \%$ of students who passed the KKM (minimum completeness criteria), and the percentage of completeness of 30 students is $80 \%$ while in cycle I, only 24 out of 30 students got higher scores than the KKM and 6 students got a score of $\leq 75$. The score obtained by the students was 78.2.

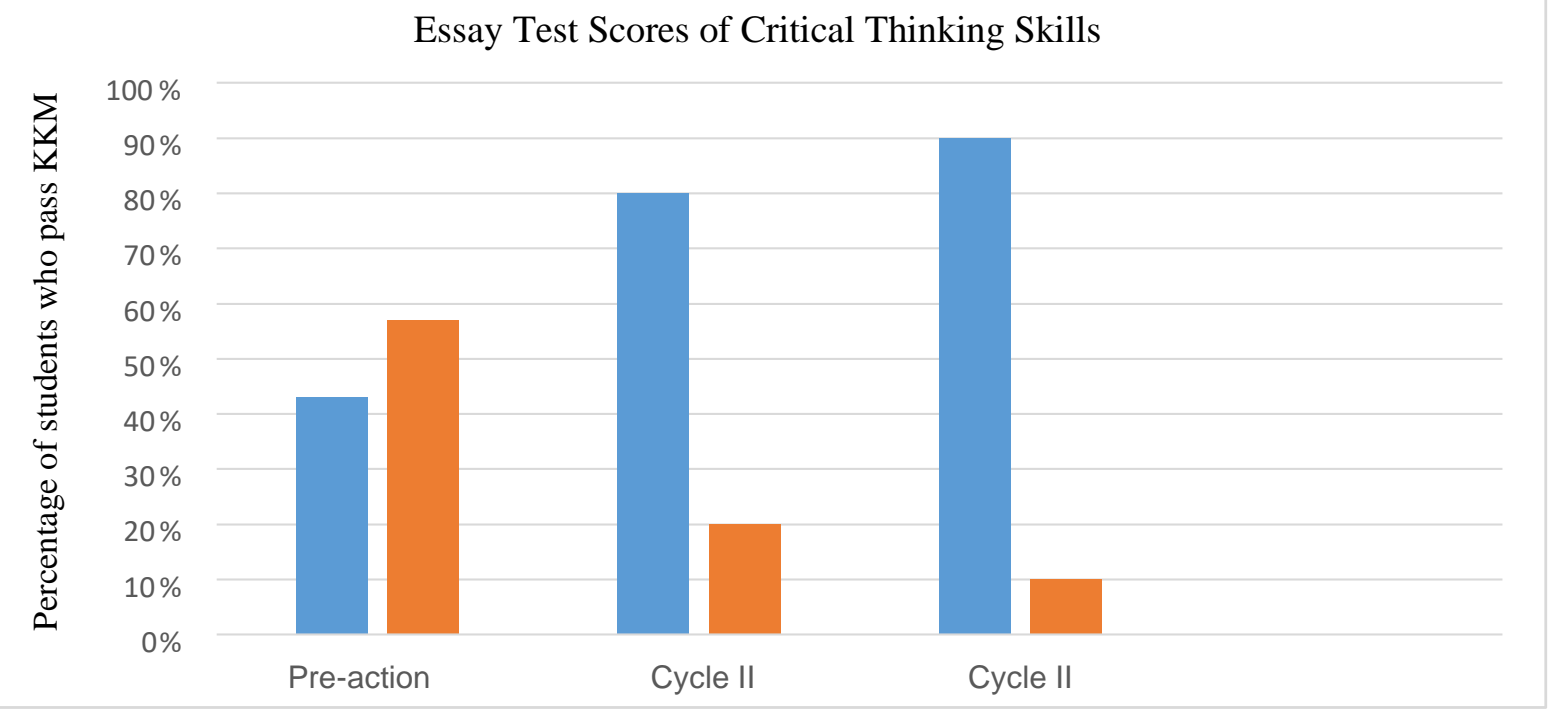

Figure 4. Diagram Comparison of Students' Critical Thinking Skill Test Results in Pre-action, Cycle I, and Cycle II

The results of the research in cycle I showed that there was an increase in the learning process. Previously, mathematics learning only used materials from books without attractive learning media. The 
Jurnal Prima Edukasia, 9 (2), 2021 - 253

Wahyu Purwaningsih, Muhammad Nur Wangid

use of the time bar media could increase the students' motivation and interest in participating in the learning process. They found it easier to calculate the duration of an activity or event by practicing using the time bar media even though there was still some limitation. The results of observations in cycle I related to the teacher's activity in using instructional media showed that it has not reached the standard score in terms of time allocation. However, in general, the teacher has involved the students in the learning activities using the time bar media. Indeed, the use of learning media makes some students more active in learning. In the pre-action, based on the results of observations and students' test scores in essay questions that required a very low level of critical thinking showed that $43 \%$ out of 30 students could complete 30 the questions and $57 \%$ of the students could not. It was because the learning process is too teacher-centered without involving students to be more active. The low students' critical thinking skills was caused by the lack of use of learning media. In total, only13 students have passed the KKM. Meanwhile, the other 17 students have not. The KKM at State Primary School Kotagede 1 is 75. The score of the students' critical thinking skill test in mathematics using the time bar media in grade IIIA of State Primary School Kotagede 1 increased from 13 students (43\%) to 24 students (80\%) who passed the KKM.

This increase was due to students' enthusiasm for learning mathematics. The content of the learning becomes less boring and less scary after the use of the time bar media. It is in line with Eryilmaz (2015) who states that learning will be more effective, efficient, and creative by using learning media. Learning media are a means to help teachers to transmit and explain materials in an interesting way. Students observed the time bar media carefully and thoroughly. They could calculate the time of an activity or event using the time bar media.

In cycle II, the learning process is almost similar to cycle I with some improvements. The teacher used the time bar media well and explained the material clearer compared to cycle I. The learning content that uses the time bar media is in accordance with the material and learning objectives. It is in line with Salvia et al. (2015) who state that the learning process in the classroom highly determines the success of students to achieve learning goals with visual materials that affect students' learning outcomes. Students found it easier to observe and understand the time bar media explained by the teacher. As stated above, in cycle II, the teacher has used the time bar media well to deliver and explain materials to students. The learning process became more attractive and interesting to students so that they can focus more on lessons. It is in accordance with Abdo and Semela (2010) in which the use of learning media can maintain the students' attention, support the learning process, and increase class performance through increased acquisition of materials. The teacher involved the students in learning to make them interested, participated, and enthusiastic in learning. It is in line with (Becker, 2006; Gee, 2008; Newby et al., 2011) in which the use of media in the teaching and learning process can arouse student desire, motivation, stimulation, and psychological influence and can facilitate positive learning outcomes. In cycle II, students were more enthusiastic about participating in learning. They listened to the teacher's explanation enthusiastically and were able to calculate the length of time of activities or events out using the time bar media. Some students became more active in proposing questions and participating in lessons. Almost all students have done the assignment given well. They did the assignment quickly according to the given time. They also received the assignment to do critical thinking skills tests in mathematics learning.

In cycle II, the result of the students' critical thinking skills test scores increased significantly. A total of 27 students $(90 \%)$ have passed the KKM, while three students $(10 \%)$ had not passed it. The students found it easier to understand and analyze a problem. They also became more enthusiastic about participating in mathematics learning with the use of the time bar media. This study has achieved the specified success criteria in which $75 \%$ of the total students have a good critical thinking skill test score. Thus, it can be said that the cycle is successful can be stopped.

The Improvement of Students' Critical Thinking Skills in Grade IIIA of State Primary School Kotagede 1

\section{Providing simple explanations}

Students' ability to provide simple explanations increased from the pretest to the second cycle test. In this stage, students analyzed questions.

\section{Identification or formulation of questions}


Jurnal Prima Edukasia, 9 (2), 2021 - 254

Wahyu Purwaningsih, Muhammad Nur Wangid

The implementation of actions in cycle I - cycle II has improved based on the results of the essay test of critical thinking skills. In cycle I, students still did not understand how to identify or formulate questions. The teacher only explains to the students to identify the point "being asked" in the question by considering sentences with a question mark. Meanwhile, in cycle II, the students' ability to identify and formulate questions has improved based on the students' answers to the critical thinking skill questions. They were able to identify and formulate questions correctly without limited to identify the sentences with a question mark. It is suitable for the statement of Dunn et al. (2010) who argue that critical thinking is affected by classroom dynamics and better meaningful efforts than worrying about the accuracy. Besides, critical thinking is a conceptualization process to analyze, synthesize, and evaluate data and information obtained from observation, reflection, reasoning, or communication as guidance to take actions (Peter, 2012).

\section{Providing simple explanations}

Based on the data obtained from the essay mathematics tests in the first cycle, the answers to these questions showed that most students already understand the questions and provide answers or solutions using simple explanations. Meanwhile, in cycle II, the students' ability to provide further explanation has also increased. It can be seen on the students' answer essay mathematics questions on the provided spaces. Students answer the questions by providing an explanation and solution to the questions. At this stage students adjusted and determined how to solve the questions to get the correct answer. The essay tests to measure students' critical thinking skills should have a high level of difficulty (McPeck, 2018; Wilson \& Peterson, 2006) in line with the objectives of critical thinking. Faiz (2012) stated that critical thinking aims to provide explanations and guarantee the validity and appropriateness of the explanations or thoughts.

Building basic skills

\section{Reasoning}

The data were obtained from the essay test. The test contains indicators and aspects of critical thinking skills enabling the students to analyze problems. In cycle I, the students' ability to answer questions by providing the reasons increased compared to pre-action. However, some students did not give reasons for the answer. Meanwhile, in cycle II, the students' ability to give reasons has increased. Students answered the questions on the provided space by giving reasons for the answer. The reasoning ability is characterized by the ability to assess the credibility of a source and doing and evaluating an observation. Assessing the credibility of a source should be based on certain criteria, so did doing and evaluating an observation. Critical thinking uses valid and reliable sources to solve a problem and to provide clear and logical reasons. Critical thinking is the individual's ability to create, judge, and provide reasons for a conclusion based on evidence (Downs, 1988). It means developing students' critical thinking skills requires students' basic abilities, for example, observing, assessing, and providing reasons for solving problems. Further, (K. D. Moore, 2014; Paul \& Elder, 2019) stated that critical thinking is not the same as intelligence, but it is an ability to think that can be improved by all people.

Concluding

\section{Concluding the results of the research}

Data were obtained from the results of tests in grade IIIA of State Primary School Kotagede 1. The teacher gave questions according to the indicators and aspects of critical thinking skills. Students should be able to analyze the problems in the questions. Students analyzed the questions to solve them. In Cycle I, some students could conclude the answers to the questions. The data showed that the students could formulate new definitions from the answers they got. Meanwhile, in cycle II, students' ability to conclude increased. It is in line with Arends and Kilcher (2010) in which critical thinking is a reflective thought to analyze arguments, identify mistakes, and to draw conclusions based on evidence. It is supported by Shamir et al. (2008) who stated that critical thinking is a process for analyzing information obtained through experience, observation, reading, and communication. Critical thinking includes the ability to think productively and reflectively and evaluate evidence.

Providing further explanations 
Jurnal Prima Edukasia, 9 (2), 2021 - 255

Wahyu Purwaningsih, Muhammad Nur Wangid

\section{Providing further explanations}

The data were obtained from the test in cycle I. The test contained questions based on the indicators and aspects of critical thinking skills. In the stage of providing a further explanation, some students answered the questions on the provided space completely by providing further explanations (detailed explanation) in accordance with the instructions and examples given by the teacher. However, some other students did not provide further explanation to the answer for example they only marked or wrote numbers on the time bar media. In cycle II, they could answer with a more complete and precise explanation on the provided space. The purpose of critical thinking is to be able to provide further explanations (Johnson, 2011). An individual who has critical thinking skills is generally curious and able to provide reasons for the answer. It is in accordance with Gambrill and Gibbs (2009) who stated that the ability to think critically produces reasonable answers and makes logical connections between elements and existing problems.

Arranging strategies and tactics

Providing solutions

The data were obtained from the critical thinking test. Some students could answer questions by providing solutions to a problem. They read the questions first, then analyze it. The ability to provide solutions to questions is characterized by the ability to decide the solution to the questions and the ability to analyze them. In Cycle II, the number of students who could provide solutions to analyze questions increased. Critical thinking is to test an opinion or idea. It also aims to assess a thought, assess value, and even evaluate the implementation or practice of thoughts and values (Sapriya, 2015). It is in accordance with Facione (2013) who stated that to realize to the ideal citizen, people should be able to develop creativity to think critically and consistently based on democratic rational knowledge and to produce useful insights. Thus, critical thinking skills are crucial for everyone to be able to solve problems and analyze information.

\section{Observation}

Observation is one important action in this research. The number of 30 students, observed by the researchers themselves. During the learning process, there is a learning observation on the charge of mathematics learning using time-wasting media. Cycle I observation is double-time meeting using timerelease media with the time-spent learning materials. The results of observation on cycle I are the average of two meetings in one cycle. The results of observation will be presented as reflective material for further action (further cycle). The first meeting in cycle I there's a slight miscommunication in the time ejection function. When time constraints can be used in measuring hours and minutes, but the teacher pointed out that time constraints can only be used in minutes. When they finished, researchers straightened out the teacher's point. This conforms to Kilpatrick et al. (2001) stated that presents mathematical concepts into various forms of mathematical representation. The time-measurement material that normally uses only hours of media but is presented in this study by time distribution. To know the student's understanding, the teacher threw several questions at the student. The teacher can reach five categories of excellent activity, 20 category activities are good, and two categories are sufficient. In cycle I of this second meeting the teacher needs to increase several aspects, which are in using learning media that are consistent with basic competence, in using time width according to the learning materials, and in the question-and-answer on time-release media.

Data derived from observations on the teachers' use of time-release media, which is that researchers observe the reliability of teachers' use of time-release media on the charge of mathematics of Cycle II. In observing Cycle II, the teacher gave the student a question regarding the matter of time measurement. The questions are used to enhance understanding of students' concepts. Concept understanding is the integration and development of knowledge from abstract to concrete. Conceptual understanding comes about because it has taken the abstraction process of factual knowledge. Understanding of concepts is not limited to the ability to provide examples, as well as understanding and formulas, but rather links between concepts, such as teachers and students engaging in question and answer (Brookhart \& Nitko, 2019; Stern et al., 2017; Yoong, 1987). The questions on question and answer activities done by the teacher to the students began to vary and be developed. After sufficient time is satisfied, teachers guide and facilitate students to use time-wasting media. This custom is with Sládek et al. (2011) suggests 
Jurnal Prima Edukasia, 9 (2), 2021 - 256

Wahyu Purwaningsih, Muhammad Nur Wangid

that the process of creating an opinion in another person's conversation through the activities of already existing experience. Students who have confidence and confidence to craft and re-explain concepts mean a person's affectation increases when understanding (Duffin \& Simpson, 2000).

Spinning around in each group, the teacher gives explanations and reinforcement about the time travel media. The teacher directs students to discuss the worksheet given and directs do any activity or activity according to the command. Not to be forgotten teachers also gave examples of calculating time in everyday life. The new knowledge students gained from the learning process can be presented through media and old knowledge gained from the experience students have gained (Miettinen, 2000).

According to the data obtained above, the teacher has performed all activities or activities. The teacher has reached nine categories of good activity, 18 category activities very good. During the second cycle of this first meeting the teacher needed to increase some aspects in order to make the results particularly satisfying.

\section{Reflection}

At this stage, reflection is carried out at the end of cycle I and cycle II. Researchers and teachers discuss the results of research in observation and tests. In the reflection stage, it is carried out to discuss the things that are obstacles and shortcomings in cycle I. This is very important to correct previous actions even though the use of time bars can improve students' critical thinking skills in mathematics learning content. Learning in schools must be able to develop critical thinking skills. Strategy, approach, model or methods, and learn media that facilitate the process of transfer information, generating student activity, and describe the problems in everyday life should be used in the study (Fajari et al., 2020; Ruggiero, 2012). The teacher has tried to carry out the learning process according to the lesson plan, but in reality, the conditions in the classroom are different from what he expected. Researchers and teachers held discussions regarding what things needed to be improved at the next meeting. There are some drawbacks, namely: the teacher does not prepare students' readiness in learning, where mathematics learning is carried out in the first hour so that students are still not ready to take part in learning, Students are still having difficulty reading number cards (knowing the time) which are attached to the time bar, There are several students in answering questions still does not provide clear, precise, and logical reasons.

The researcher took the cycle II of action to ensure that the first cycle of action had been successfully implemented. Researchers also provide reasons for suggestions for improving learning activities in the next cycle, namely in cycle II. Cycle II is useful to ensure that cycle I have been achieved. in cycle II, there was an increase in the results of the essay test on critical thinking skills in mathematics learning content. In the test results, there was an increase in each cycle. (Fan et al., 2015; Soylu \& Akkoyunlu, 2009) in their research can also conclude there is an interaction between learning media, learning styles, and learning outcomes in students. The test results showed that in cycle I the number of students who reached the completeness criteria was $80 \%$ and in cycle II $90 \%$. In the second cycle of 30 students, 27 of them had reached the success criteria.

From the data above, the researcher and the teacher felt that the action was sufficiently stopped in cycle II because the average of all students who took the test showed that they had reached the expectation criteria, namely $75 \%$ of the total students had achieved very good classification.

\section{Conclusion}

Based on the results of the research and discussion above, it can be concluded that the students' critical thinking skills in grade IIIA of State Primary School Kotagede I increased with the use of the time bar media. The increase occurred in the learning process and outcome. The learning process has encouraged students to think critically through the provision of a series of activities with the use of the time bar media. It makes the students more active in learning in analyzing questions. The time bar media can concretize abstract material (with lines and numbers on the time bar) so that students can hold, practice, and use the time bar media directly. Although the media are large and long, they are colorful and easy to carry and even can be easily folded. The media are also durable with the use of a magnet to attach the number and even fitted with thematic pictures. In terms of outcomes, students' critical thinking skills increase based on the results of the essay test. It increases from $43 \%$ in the pre-action to $80 \%$ in cycle I and $90 \%$ in cycle II. The learning process runs well. Indeed, there are some limitations in cycle 
Jurnal Prima Edukasia, 9 (2), 2021 - 257

Wahyu Purwaningsih, Muhammad Nur Wangid

I, but they could be fixed in cycle II. The teacher has also used the time bar media according to the method, and function which makes the students be able to use the time bar media as concrete learning media.

Based on the results of the research to improve students' critical thinking skills by using the time bar media, the researcher has formulated some suggestions. Teachers are expected to use the time bar media and other learning media in other subjects and are required to increase their creativity in developing learning media. Students are expected to be able to improve their critical thinking skills.

The results of the study presented are important data obtained from the results of data collection in the field (test results, questionnaires, interviews, documents, etc.). Research results can be supplemented by tables, figures, or graphs to clarify the results of the study. Avoid presenting similar data in separate tables. Tables, figures and graphics must be commented or discussed. All tables, figures and graphics must be centered and numbered consecutively. For qualitative research, the results section contains detailed sections in the form of sub-topics that are directly related to the research focus and categories.

The discussion in the article aims to: (1) answer the problem formulation and research questions; (2) shows how the findings were obtained; (3) interpret research findings; (4) linking research findings to established knowledge structures; and (5) bringing up new theories or modification of existing theories. This part of the discussion should contain the benefits of the research results, not the repetition results. The analysis must address the stated gap.

In answering the formulation of the problem and research questions, the results of the study must be concluded explicitly. Interpretation of findings is carried out using logic and existing theories. Findings in the form of reality in the field are integrated/linked with the results of previous studies or with existing theories. For this purpose, there must be a reference. In bringing up new theories, old theories can be confirmed or rejected, some may need to modify theories from old theories.

\section{References}

Abdo, M., \& Semela, T. (2010). Teachers of poor communities: the tale of instructional media use in primary schools of Gedeo Zone, Southern Ethiopia. Australian Journal of Teacher Education, 35(7), 78-92. https://doi.org/10.14221/ajte.2010v35n7.7

Adekola, G. (2010). The impact of instructional media on the education of youths on HIV/AIDS in Nigeria urban communities. International Journal of Scientific Research in Education, 3(June), 64-72.

AECT. (2021). Association for Educational Communications and Technology. AECT.ORG. https://www.aect.org/

Ahonen, A. K., \& Kinnunen, P. (2015). How do students value the importance of twenty-first century skills? Scandinavian Journal of Educational Research, 59(4), 395-412. https://doi.org/10.1080/00313831.2014.904423

Akay, D. E., \& Gumusoglu, E. K. (2020). The impact of learning management systems on students'achievement in language exams. Turkish Online Journal of Distance Education, 21(4), 206-222. https://doi.org/10.17718/TOJDE.803410

Arends, R. I., \& Kilcher, A. (2010). Teaching for student learning: Becoming an accomplished teacher. In Teaching for Student Learning: Becoming an Accomplished Teacher. https://doi.org/10.4324/9780203866771

Arikunto, S. (2005). Manajemen penelitian. Rineka Cipta.

Arke, E. T. (2005). Media literacy and critical thinking: Is there a connection?

Becker, K. (2006). Pedagogy in commercial videos. In Games and Simulations in Online Learning (Vol. 2006, pp. 21-48). IGI Global. https://doi.org/10.4018/978-1-59904-304-3.ch002

Brookhart, S. M., \& Nitko, A. J. (2019). Educational assessment of students (8th ed.). Pearson.

Buckingham, D. (2008). Youth, media, identity. The MIT Press.

Changwong, K., Sukkamart, A., \& Sisan, B. (2018). Critical thinking skill development: Analysis of a new learning management model for Thai high schools. Journal of International Studies, 11(2), 37-48. https://doi.org/10.14254/2071-8330.2018/11-2/3

Copyright (C) 2021, Jurnal Prima Edukasia, ISSN 2338-4743 (print), ISSN 2460-9927 (online) 
Jurnal Prima Edukasia, 9 (2), 2021 - 258

Wahyu Purwaningsih, Muhammad Nur Wangid

Chusni, M. M., Saputro, S., Suranto, S., \& Rahardjo, S. B. (2020). Review of critical thinking skill in indonesia: Preparation of the 21st century learner. Journal of Critical Reviews, 7(09), 12301235. https://doi.org/10.31838/jcr.07.09.223

Courville, K. (2011). Technology and its use in education: Present roles and future prospects. 2011 Recovery School District Technology Summit, 1-19.

Davidson, B., \& Dunham, R. A. (1997). Assessing EFL student progress in critical thinking with the Ennis-weir critical thinking essay test! JALT Journal, 19(1), 43-57.

Dixon, P. A. (2017). Extensive listening, teacher proficiency and 21 st century skills: Interview with Dr Willy A. Renandya. RELC Journal, 48(1), 153-158. https://doi.org/10.1177/0033688217695658

Downs, J. R. (1988). Strategies for teachers: Teaching content and thinking skills. Second edition. NASSP Bulletin, 72(508), 119-119. https://doi.org/10.1177/019263658807250832

Duffin, J. M., \& Simpson, A. P. (2000). A search for understanding. The Journal of Mathematical Behavior, 18(4), 415-427. https://doi.org/10.1016/S0732-3123(00)00028-6

Dunn, D. S., Beins, B. B., McCarthy, M. A., \& Hill, G. W. (2010). Best practices for teaching beginnings and endings in the psychology major. Oxford University Press.

Duron, R., Limbach, B., \& Waugh, W. (2006). Critical thinking framework for any discipline. International Journal of Teaching and Learning in Higher Education, 17(2), 160-166. https://doi.org/10.1016/j.nepr.2006.09.004

Eryilmaz, S. (2015). E-learning as a teaching strategy actively used in FATIH Project. European Journal of Educational Research, 4(1), 38-47. https://doi.org/10.12973/eu-jer.4.1.38

Facione, P. A. (2013). Critical thinking: What it is and why it counts. In Insight Assesment. Measured Reasons and The California Academic Press. https://www.nyack.edu/files/CT_What_Why_2013.pdf

Faiz, F. (2012). Thinking skill pengantar menuju berpikir kritis. SUKA Press UIN Sunan Kalijaga.

Fajari, L. E., Sarwanto, S., \& Chumdari, C. (2020). Improving elementary school's critical thinking skills through three different learning media viewed from learning styles. Journal of E-Learningg And Knowledge Society, 16(1), 55-64. https://doi.org/10.20368/1971-8829/1135193

Fan, K. K., Xiao, P. wei, \& Su, C. H. (2015). The effects of learning styles and meaningful learning on the learning achievement of gamification health education curriculum. Eurasia Journal of Mathematics, Science and Technology Education, 11(5), 1211-1229. https://doi.org/10.12973/eurasia.2015.1413a

Farindhani, D. A., \& Wangid, M. N. (2019). Scientific-based pictorial storybook with project-based learning method for improving the critical thinking skills of elementary school students. Jurnal Prima Edukasia, 7(1), 94-105. https://doi.org/10.21831/jpe.v7i1.8807

Gambrill, E., \& Gibbs, L. (2009). Critical thinking for helping professionals: A skills-based workbook. Oxford University Press.

Gee, J. P. (2008). Learning and games. In K. Salen (Ed.), The Ecology of Games: Connecting Youth, Games, and Learning (pp. 21-40). The MIT Press. https://doi.org/10.1162/dmal.9780262693646.021

Heo, J. (2012). The effect of using three types of instructional media on comprehension and motivation of korean college students in an online course. University of Nevada.

Hootstein, E. W. (1994). Motivating middle school students to learn. Middle School Journal, 25(5), 31-34. https://doi.org/10.1080/00940771.1994.11495219

Ingwarni, S. (2018). Developing the socioculture-based thematic-integrative learning module for improving the learning motivation and the critical thinking. Jurnal Prima Edukasia, 6(2), 157165. https://doi.org/10.21831/jpe.v6i2.9447

Johnson, E. B. (2011). Contextual teaching and learning: Menjadikan kegiatan belajar mengajar mengasyikkan dan bermakna. Kaifa.

Jones, C., \& Pimdee, P. (2017). Innovative ideas: Thailand 4.0 and the fourth industrial revolution. 
Jurnal Prima Edukasia, 9 (2), 2021 - 259

Wahyu Purwaningsih, Muhammad Nur Wangid

Asian International Journal of Social Sciences, 17(1), 4-35.

https://doi.org/10.29139/aijss.20170101

Karakoc, M. (2016). The significance of critical thinking ability in terms of education. International Journal of Humanities and Social Science Invention, 6(7), 81-84. http://www.ijhssnet.com/journals/Vol_6_No_7_July_2016/10.pdf

Kemmis, S., McTaggart, R., \& Nixon, R. (2014). The action research planner. Springer.

Kilpatrick, J., Swafford, J., \& Findell, B. (2001). Adding it up. In In International Journal for Vitamin and Nutrition Research (Vol. 54). National Academies Press. https://doi.org/10.17226/9822

McPeck, J. E. (2018). Critical thinking and education. Routledge.

Menteri Pendidikan dan Kebudayaan Republik Indonesia. (2016). Peraturan Menteri Pendidikan dan Kebudayaan Republik Indonesia Nomor 22 Tahun 2016 tentang Standar Proses Pendidikan Dasar dan Pendidikan Menengah.

Miettinen, R. (2000). The concept of experiential learning and John Dewey's theory of reflective thought and action. International Journal of Lifelong Education, 19(1), 54-72. https://doi.org/10.1080/026013700293458

Moore, B. N., \& Parker, R. (2014). Critical thinking (11th ed.). McGraw-Hill Education.

Moore, K. D. (2014). Effective instructional strategies: From theory to practice. Sage Publications.

Murawski, L. M. (2012). Critical thinking in the classroom ... and beyond. Journal of Learning in Higher Education, 10(1).

Newby, T. J., Stepich, D. A., Lehman, J. D., Russell, J. D., \& Leftwich, A. O. (2011). Educational technology for teaching and learning. Perason Education, Inc.

Paul, R., \& Elder, L. (2019). The miniature guide to critical thinking concepts and tools. Rowman \& Littlefield.

Peter, E. E. (2012). Critical thinking: Essence for teaching mathematics and mathematics problem solving skills. African Journal of Mathematics and Computer Science Research, 5(3). https://doi.org/10.5897/AJMCSR11.161

Putra, P. D. A., \& Sudarti, S. (2015). Pengembangan sistem e-learning untuk meningkatkan keterampilan berpikir kritis mahasiswa pendidikan fisika. Jurnal Fisika Indonesia, 19(55), 4548. https://doi.org/10.22146/jfi.24373

Rasiman, R. (2012). Penelusuran proses berpikir kritis dalam menyelesaikan masalah matematika bagi siswa dengan kemampuan matematika tinggi. Jurnal Pendidikan, Vol. 3(1), 12. https://doi.org/10.26877/aks.v3i1/Maret.221

Robbins, S. P., \& Judge, T. A. (2017). Organizational behavior (17th ed.). Pearson Education Limited.

Ruggiero, V. R. (2012). Beyond feelings: A guide to critical thinking. McGraw-Hill.

Salvia, I. M., Mashudi, M., \& Sulistyarini, S. (2015). Penerapan metode problem solving dalam meningkatkan keterampilan berpikir kritis siswa mata pelajaran ekonomi. Jurnal Pendidikan Dan Pembelajaran, 4(3), 1-16. https://jurnal.untan.ac.id/index.php/jpdpb/article/view/9192/0

Sapriya, S. (2015). Pendidikan IPS. Remaja Rosdakarya.

Sari, A. R. P., \& Suyanta, S. (2021). Karakteristik instrumen integrated assessment untuk mengukur critical thinking skills dan science process skills. Measurement in Educational Research, 1(1), 26-38. https://doi.org/10.33292/meter.v1i1.108

Scott, S. (2008). Perceptions of students' learning critical thinking through debate in a technology classroom: A case study. The Journal of Technology Studies, 34(1). https://doi.org/10.21061/jots.v34i1.a.5

Shamir, A., Zion, M., \& Levy, O. S. (2008). Peer tutoring, metacognitive processes and multimedia problem-based learning: The effect of mediation training on critical thinking. Journal of Science Education and Technology, 17(4), 384-398. https://doi.org/10.1007/s10956-008-9108-4

Shihab, M. Q. (2010). Membumikan Al-Quran, fungsi, dan peran wahyu dalam masyarakat. Mizan Media Utama. 
Jurnal Prima Edukasia, 9 (2), 2021 - 260

Wahyu Purwaningsih, Muhammad Nur Wangid

Sládek, P., Miléŕ, T., \& Benárová, R. (2011). How to increase students' interest in science and technology. Procedia - Social and Behavioral Sciences, 12, 168-174.

https://doi.org/10.1016/j.sbspro.2011.02.024

Smaldino, S. E., Lowther, D. L., \& Mims, C. (2010). Instructional technology and media for learning. Revista Mexicana de Investigación Educativa, 15(44), 191-196. https://www.redalyc.org/pdf/140/14012513011.pdf

Soylu, M. Y., \& Akkoyunlu, B. (2009). The effect of learning styles on achievement in different learning. The Turkish Online Journal of Educational Technology, 8(4), 43-50.

Stern, J., Lauriault, N., \& Ferraro, K. (2017). Tools for teaching conceptual understanding, elementary: Harnessing natural curiosity for learning that transfers. Corwin.

Wallace, E. D. (2015). Developing critical thinking skill: assessing the effectiveness of workbook exercise. Journal of College Teaching \& Learning, 12(56).

Welch, K. C., Hieb, J., \& Graham, J. (2015). A systematic approach to teaching critical thinking skills to electrical and computer engineering undergraduates. American Journal of Engineering Education (AJEE), 6(2), 113-124. https://doi.org/10.19030/ajee.v6i2.9506

Widodo, T. (2009). Fisika untuk SMA/ MA Kelas X. Pusat Perbukuan Dapartemen Nasional.

Wilson, S. M., \& Peterson, P. L. (2006). Theories of learning and teaching what do they mean for educators? National education association. National Education Association.

Yoong, W. K. (1987). Aspects of mathematical understanding. Singapore Journal of Education, 8(2), 45-55. https://doi.org/10.1080/02188798708547623

Zulmaulida, R., Wahyudin, W., \& Dahlan, J. A. (2018). Watson-Glaser's critical thinking skills. Journal of Physics: Conference Series, 1028, 012094. https://doi.org/10.1088/17426596/1028/1/012094 